\title{
Spodoptera frugiperda (J. E. SMITH, 1797) (LEPIDOPTERA: NOCTUIDAE) CONTROL AND PRODUCTIVE PERFORMANCE OF BT MAIZE GENOTYPES
}

\author{
Ana Maria Nascimento Scoton ${ }^{1}$, Paulo Eduardo Degrande ${ }^{1}$, Mariany Balbueno da Silva ${ }^{1}$, Filipe \\ Lemos Jacques $^{1}$, André Luis Faleiros Lourençãó ${ }^{2}$, Ellen Patricia de Souza ${ }^{1}$ \\ ${ }^{1}$ Federal University of Grande Dourados, E-mail: anamscoton@gmail.com, paulodegrande@ufgd.edu.br, \\ marianybalbuena09@hotmail.com, fljacques@gmail.com, ellen_psouza@hotmail.com \\ ${ }^{2}$ MS Foundation for Research and Diffusion of Agricultural Technologies, E-mail: andre@ fundacaoms.org.br
}

\section{ABSTRACT}

The purpose of this work was to evaluate the yield performance of Bt maize hybrids under field conditions with damage of the Spodoptera frugiperda in a completely randomized blocks design, under a factorial scheme, with four replications. Six treatments (five Bt maize hybrids and one non-Bt hybrid) were evaluated, with and without control of the S. frugiperda. In the evaluations of number of larvae and average damage scores on maize plants there was a lower incidence and lower damage of larvae on the genotypes containing Leptra ${ }^{\circledR}$ and Viptera $3^{\circledR}$ technologies and for the productive parameters there was no significant difference between the studied genotypes, even with and without chemical control of the pest. It was concluded that there are genotypes of corn resistant to $S$. frugiperda, however, there was no significant difference in the yield performance of the different hybrids when comparing the difference between lack of control and chemical control in the infestation conditions found in this study. This suggests that the levels of economic damage of $S$. frugiperda on corn crop are higher than the levels of infestation occurred in the study.

Keywords: Fall armyworm, Zea mays, Bt Corn, Cry protein, Vip3A protein.

\section{Spodoptera frugiperda (J. E. SMITH, 1797) (LEPIDOPTERA: NOCTUIDAE) CONTROLE E DESEMPENHO PRODUTIVO DE GENÓTIPOS DE MILHO BT}

\section{RESUMO}

O objetivo deste trabalho foi avaliar o desempenho produtivo de híbridos de milho e as eficácias das tecnologias Bt, em condições de campo, sob ataque da Spodoptera frugiperda. Utilizou-se o delineamento experimental em blocos casualizados, sob esquema fatorial, com quatro repetições. Foram avaliados seis tratamentos (cinco híbridos de milho Bt e um híbrido não-Bt), com e sem controle da $S$. frugiperda. Nas avaliações de número de lagartas e notas 
médias de lesões em plantas de milho, houve uma menor incidência e menores lesões foliares de lagartas nos genótipos contendo as tecnologias Leptra ${ }^{\circledR}$ e Viptera $3^{\circledR}$ e para os parâmetros produtivos não houve diferença significativa entre os genótipos estudados, mesmo com e sem controle químico da praga. Conclui-se que há genótipos de milho resistente a S. frugiperda, porém não houve diferença significativa do desempenho produtivo dos diferentes híbridos quando comparados a diferença entre ausência de controle e controle químico nas condições de infestação deste estudo. Isso sugere que os níveis de dano econômico de $S$. frugiperda na safra de milho são superiores aos níveis de infestação ocorridos no estudo.

Palavras-chave: Lagarta-do-cartucho, Zea mays, milho transgênico, proteína Cry, proteína Vip3A.

\section{INTRODUCTION}

Among grain cultures, maize (Zea mays L.) stands out as one of the most important. The economic importance of this culture is due to the many forms of its utilization, which embraces from animal feeding to high technology industry (DUARTE et al., 2017). On 2017/2018 crop, Brazil produced 95 million tons of maize, with First Crop (Summer Crop) reaching approximately 26.8 million tons, while Second Crop (Winter Crop) reached 53.9 million tons (CONAB, 2019).

With many Brazilian regions cultivating maize and being used to conduct two crops of sowing, there is intense cultivations and various climatic conditions, leading to a frequency of occurrence of insect pests. Among the pests that attack maize, the fall armyworm Spodoptera frugiperda (J. E. Smith, 1797) must be noted. As a polyphagous caterpillar, it is considered the main plague of maize culture in Brazil (CRUZ et al., 2012), for causing damages in all of its development stages.

In the past, in order to fight $S$. frugiperda, the farmers opted, mostly, for chemical control. And, because it was conducted without planning, it resulted in a selection of populations resistant to a vast array of insecticides, which hampered the control of this plague (YU et al., 2003).

Due to this, there was a great adoption of biotechnologies in order to aid the S. frugiperda management. In the 2016/2017 crop, these maize technologies were used in 90\% of the cultivated area (CÉLERES, 2017). However, the commercial liberation of maize events that express 
insecticide proteins of Bacillus thuringiensis Berliner (Bt) and its constant adoption made the pest populations be exposed to a great pressure of selection, causing the resistance evolution.

This evolution can reduce the effectiveness of insecticide proteins based on $B$. thurigiensis produced by transgenic cultures (TABASHNIK et al., 2013). Studies already confirmed the resistance of $S$. frugiperda to maize technologies that express the proteins Cry1F and Cry1 Ab (FARIAS et al., 2014; OMOTO et al., 2016) and also combined proteins Cry1 (BERNARDI et al., 2015b).

In front of this, the objective of this work was to evaluate the control and the productive performance of Bt maize hybrids in field conditions under attack of $S$. frugiperda.

\section{MATERIAL AND METHODS}

The study was conducted in the period from October 30, 2018 to April 10, 2019, at the Agrarian Sciences Experimental Farm of the Federal University of Grande Dourados (UFGD), located at the municipality of Dourados, state of Mato Grosso do Sul, Brazil. The location is situated at latitude $22^{\circ} 14^{\prime} \mathrm{S}$, longitude $54^{\circ} 59^{\prime} \mathrm{O}$ and altitude of $434 \mathrm{~m}$. The area soil is classified as Dystroferric Red Latosol. The meteorological data were obtained from the experimental station of Embrapa Western Agriculture.

The experimental design the completely randomized blocks, with six maize hybrids being tested. Among them, five had different Bt biotechnological events and one did not. Bt (Table 1), with and without control of S. frugiperda, in factorial scheme (6x2), consisting in 6 cultivars, with and without control of the fall armyworm (2) and 4 replications.

Initially, the herbicide burndown control of fall germinating weeds of the area and the insecticide (Premio ${ }^{\circledR} 0.1 \mathrm{~L} \mathrm{ha}^{-1}$ and Engeo Pleno ${ }^{\circledR} 0.3 \mathrm{~L} \mathrm{ha}^{-1}$ ) application were conducted, in order to ensure that the area was free of insect pests at the installation of the work, and then, the sowing lines were demarked with a fertilizer-sower (Baldan Solografic Directa 4500) with 9 lines spaced in 0.45 meters and with chisel plow for fertilizer, being used $300 \mathrm{~kg}^{-h a^{-1}}$ of the 8-30-10 (NPK) formula at the sowing.

The maize sowing was conducted manually on November 06, 2018. Each parcel consisted in 9 lines spaced in 0.45 meters between each other and 5.5 meters of length, with sowing density of four seeds per linear meter, with the seed beings treated with Gaucho ${ }^{\circledR}\left(7 \mathrm{~g}\right.$ of a.i. $\mathrm{kg}^{-1}$ of seed). As an operational safety measure, antivapour masks and $\mathrm{Curad}^{\circledR}$ nitrile gloves were used in order 
to avoid the direct contact with the pesticide. A 3-meter space was reserved between the experimental units, destined to machinery traffic. There was conducted some irrigations with sprinkles during the culture development.

The infestation of $S$. frugiperda in the area occurred naturally in all the parcels. The insecticide applications, aiming at keeping control of $S$. frugiperda on the parcels that demanded absence of the fall armyworm attack were conducted using a sprayer (KO Cross-s 2000) equipped with a $14 \mathrm{~m}$ bar using the pesticide Pirate ${ }^{\circledR} \mathrm{SC}\left(240 \mathrm{~g}\right.$ of a.i. $\left.\mathrm{L}^{-1}\right)$ on the dose of $0.8 \mathrm{~L}$ formulated product $\mathrm{ha}^{-1}$. This control was conducted weekly in every parcel that consisted on treatments with plague control, avoiding the presence of this plague-insect. The weed management was conducted with manual cutting and use of herbicides Atrazina Atanor ${ }^{\circledR}$ SC $\left(500 \mathrm{~g}\right.$ of a.i. $\left.\mathrm{L}^{-1}\right)$ on the dose of $3 \mathrm{~L}$ p.c. $\mathrm{ha}^{-1}$ and $\mathrm{Sanson}^{\circledR} 40 \mathrm{SC}\left(40 \mathrm{~g}\right.$ of a.i. $\left.\mathrm{L}^{-1}\right)$ on the dose of 1.25 $\mathrm{L} \mathrm{ha}^{-1}$. For the disease control there was conducted an application of the fungicide Aproach ${ }^{\circledR}$ Prima on the dose of $0.4 \mathrm{~L} \mathrm{ha}^{-1}$. At 25 days after emergence (DAE) of the plants there was conducted the coverage fertilization with $200 \mathrm{~kg} \cdot \mathrm{ha}^{-1}$ of urea.

The evaluations of the foliar lesions of S. frugiperda in maize were conducted at every five days, from 12 DAE of plants, in the central leaves of the 10-plant cartridge on the center lines of each parcel, assigning a lesion note for every plant in accord with an adapted Davis scale (1- no visual lesion to 9 - severe lesions) (DAVIS et al., 1992). Also, there was evaluated the number of caterpillars present on the cartridge of these maize plants, with leaves being cautiously removed in a way that could allow the counting of small, medium and large caterpillars, obtaining a total sum of caterpillars. After complete flowering, there was evaluated, in 10 plants per parcel, the stand and the height of the plants, measuring from the base to the insertion of the last leaf.

Two central lines from each parcel were conserved intact, destinated to, at the end of the experiment, evaluate the productivity indicators, comparing the productive development of each hybrid when submitted to pest control and when in the absence of it, by means of reed diameter, number of cobs per plant of 10 plants per parcel, weight of grains in an area of $3.6 \mathrm{~m}^{2}$ harvested from each parcel, and one thousand grains mass, conducted according with the indicated in the rules for seeds analysis - RAS (BRASIL, 2009), with the value being corrected to $13 \%$ of humidity. Also, there was evaluated the total number of grains, number of grain rows and cobs length, evaluating 10 cobs per parcel. 
The analyses were conducted using the statistical software R Core Team ${ }^{\circledR}$. The data of mean number of caterpillars were compared by contrast of the negative binomial model, at $5 \%$ of probability, and the data of mean notes of leaf lesions were compared by the Friedman test, also at $5 \%$ of probability. The data referring to productive performance were obtained from the difference between treatments with and without control of $S$. frugiperda, estimated in percentage, with means being compared by Kruskal-Wallis test at $5 \%$ of probability. There was no comparison made regarding the hybrids because they have different genotypes (non-isogenic hybrids).

Table 1. Bt maize commercial technologies, their biotechnological events and proteins expressed on plants in the respective genotypes of maize studied in the experiment. Dourados, Mato Grosso do Sul State, Brazil, 2019.

\section{Commercial}

Bt

Event

Technology

$\begin{array}{cc}\text { Herculex }^{\circledR} & \text { TC1507 } \\ \text { Leptra }^{\circledR} & \text { TC1507+MON810 } \\ \text { Powercore }^{\circledR} & \text { MON89034+TC1507 } \\ \text { Viptera3 }^{\circledR} & \text { MIR162 } \\ & \text { MON89034+MON88 }\end{array}$

017
Expressed Protein

Cry1F

Cry1F+Cry1 Ab+ VIP3Aa20

Cry1 A.105+Cry2Ab2+Cry1F

VIP3Aa20

Cry1A.105+Cry2Ab2+Cry3Bb1
Hybrid Brand

Name

Non-Bt

$---$

P3380HR ${ }^{\circledR}$

P3431VYH ${ }^{\circledR}$

MG600PW $^{\circledR}$

DefenderVIP ${ }^{\circledR}$

DKB290PRO3 $^{\circledR}$

Source: National Biosafety Technical Commission (CTNBio), 2018.

\section{RESULTS AND DISCUSSION}

The infestation of $S$. frugiperda occurred naturally and uniformly in the experimental area, with the presence of the pest being noticed in all the experimental units. The mean numbers of caterpillars differed significantly between the treatments, with less occurrence, in general, of caterpillars on the hybrids containing the Leptra ${ }^{\circledR}$ and Viptera $3^{\circledR}$ technologies (Table 2).

On the first evaluations (12 and $17 \mathrm{DAE}$ ), there was low variability for the mean number of caterpillars (Table 2). Yet at $22 \mathrm{DAE}$, the values for mean number of caterpillars were higher, differing for hybrids and for absence and presence of $S$. frugiperda control. In the absence of control of the plague, the hybrid containing the Herculex ${ }^{\circledR}$ technology obtained the highest values 
for mean number of caterpillars, even when compared to the non-Bt hybrid. This is due to the maize $S$. frugiperda resistance to the protein expressed by the Herculex ${ }^{\circledR}$ technology (Cry1F), fact also evidenced in the study of Farias et al (2014), about the resistance of populations of this plague derived from many Brazilian regions to the Cry1F protein. This suggests that Cry1F resistant populations of $S$. frugiperda are more adapted to Herculex ${ }^{\circledR}$ hybrids than in non-Bt cultivars.

On this period, the hybrid containing the Viptera $3^{\circledR}$ technology was the only that did not present occurrence of caterpillars. Bernardi et al. (2015a) described the efficiency of the Vip3Aa20 protein on the control of S. frugiperda and Diatraea saccharalis on corn, which confirms the technology stability until the last crop even with the quick evolution capacity of resistance presented by the insect. The authors also described that from the point of view of keeping the plants free from plagues, this technology is more effective than the sequential applications of insecticide.

At $27 \mathrm{DAE}$, in the absence of control of the plague, the $\mathrm{Bt}$ maize hybrids containing Leptra ${ }^{\circledR}$ and Viptera $3^{\circledR}$ technologies were the only ones that did not present caterpillars occurrence. The higher incidence happened in the hybrid with Herculex ${ }^{\circledR}$ technology, overcoming even the non-Bt genotype. At $32 \mathrm{DAE}$, it can be observed that the hybrids with Herculex ${ }^{\circledR}$, VT PRO $3^{\circledR}$ technologies and the non-Bt obtained the highest means, not statistically differing between each other. This suggests that VT PRO $3^{\circledR}$ technology has failure to control fall armyworm significantly, probably showing resistance like Herculex ${ }^{\circledR}$.

Similarly, the hybrid containing the Powercore ${ }^{\circledR}$ technology was the only one that presented significant difference for absence and presence of chemical control, with the higher number of caterpillars where there were no applications of insecticides (Table 2). Yet at 37 DAE, it is noteworthy that the hybrid which contained the Viptera $3{ }^{\circledR}$ technology did significantly differed from the hybrids that contained the Powercore ${ }^{\circledR}$, VT PRO $3^{\circledR}$ and Herculex ${ }^{\circledR}$ technologies. In studies where S. frugiperda breeds were selected in lab, it can be observed resistance of this plague to the proteins Cry1 A.105, Cry2Ab2 and Vip3 Aa20 (BERNARDI et al., 2015b, 2016, 2017). Until 32 DAE, the genotype which contained the Viptera $3^{\circledR}$ technology presented performance like the genotype which contained the Leptra ${ }^{\circledR}$ technology, which did not presented occurrence of the pest. 
Table 2. Mean number \pm standard error of Spodoptera caterpillars found in the 10-plant cartridge per parcel of different Bt maize hybrids at 12, 17, 22, 27, 32,37, 42, and 47 days after emergence (DAE). Dourados, Mato Grosso do Sul State, Brazil, 2020.

\begin{tabular}{|c|c|c|c|c|}
\hline \multirow{2}{*}{ Hybrid } & \multicolumn{2}{|c|}{12 DAE } & \multicolumn{2}{|c|}{17 DAE } \\
\hline & With control & Without control & With control & Without control \\
\hline P3380HR ${ }^{\circledR}$ & $0.00 \pm 0.00 \mathrm{Ab}^{*}$ & $0.00 \pm 0.00 \mathrm{Ab}^{*}$ & $1.75 \pm 1.03 \mathrm{Aa}$ & $1.25 \pm 0.47 \mathrm{Aa}$ \\
\hline P3431VYH ${ }^{\circledR}$ & $0.00 \pm 0.00 \mathrm{Ab}^{*}$ & $0.00 \pm 0.00 \mathrm{Ab}^{*}$ & $0.00 \pm 0.00 \mathrm{Ab}^{*}$ & $0.00 \pm 0.00 \mathrm{Ab}^{*}$ \\
\hline MG600PW ${ }^{\circledR}$ & $0.25 \pm 0.25 \mathrm{Aa}$ & $0.25 \pm 0.25 \mathrm{Aa}$ & $0.00 \pm 0.00 \mathrm{Bb}^{*}$ & $0.25 \pm 0.25 \mathrm{Aa}$ \\
\hline DefenderVIP ${ }^{\circledR}$ & $0.00 \pm 0.00 \mathrm{Ab}^{*}$ & $0.00 \pm 0.00 \mathrm{Ab}^{*}$ & $0.25 \pm 0.25 \mathrm{Aa}$ & $0.25 \pm 0.25 \mathrm{Aa}$ \\
\hline $\mathrm{DKB}^{290 P R O 3}{ }^{\circledR}$ & $0.00 \pm 0.00 \mathrm{Bb}^{*}$ & $0.50 \pm 0.28 \mathrm{Aa}$ & $0.25 \pm 0.25 \mathrm{Aa}$ & $2.50 \pm 1.55 \mathrm{Aa}$ \\
\hline $\mathrm{NS} 70^{\circledR}$ & $0.00 \pm 0.00 \mathrm{Ab}^{*}$ & $0.25 \pm 0.25 \mathrm{Aa}$ & $0.00 \pm 0.00 \mathrm{Ab}^{*}$ & $0.75 \pm 0.25 \mathrm{Aa}$ \\
\hline \multirow{2}{*}{ Hybrid } & \multicolumn{2}{|c|}{22 DAE } & \multicolumn{2}{|c|}{27 DAE } \\
\hline & With control & Without control & With control & Without control \\
\hline P3380HR ${ }^{\circledR}$ & $1.00 \pm 1.00 \mathrm{Ba}$ & $5.25 \pm 1.54 \mathrm{Aa}$ & $1.25 \pm 0.25 \mathrm{Ba}$ & $6.00 \pm 1.47 \mathrm{Aa}$ \\
\hline P3431VYH ${ }^{\circledR}$ & $0.00 \pm 0.00 \mathrm{Bc}^{*}$ & $0.50 \pm 0.28 \mathrm{Ab}$ & $0.00 \pm 0.00 \mathrm{Ab}^{*}$ & $0.00 \pm 0.00 \mathrm{Ac}^{*}$ \\
\hline MG600PW $^{\circledR}$ & $0.25 \pm 0.25 \mathrm{Ab}$ & $1.25 \pm 0.25 \mathrm{Ab}$ & $0.25 \pm 0.25 \mathrm{Aa}$ & $0.50 \pm 0.28 \mathrm{Ab}$ \\
\hline DefenderVIP ${ }^{\circledR}$ & $0.00 \pm 0.00 \mathrm{Ac}^{*}$ & $0.00 \pm 0.00 \mathrm{Ac}^{*}$ & $0.00 \pm 0.00 \mathrm{Bb}^{*}$ & $0.00 \pm 0.00 \mathrm{Bc}^{*}$ \\
\hline DKB290PRO3 ${ }^{\circledR}$ & $0.75 \pm 0.47 \mathrm{Ab}$ & $2.50 \pm 1.25 \mathrm{Ab}$ & $0.00 \pm 0.00 \mathrm{Bb}^{*}$ & $2.25 \pm 0.62 \mathrm{Ab}$ \\
\hline $\mathrm{NS} 70^{\circledR}$ & $2.00 \pm 1.08 \mathrm{Ab}$ & $2.50 \pm 1.55 \mathrm{Ab}$ & $1.00 \pm 1.00 \mathrm{Aa}$ & $1.25 \pm 0.25 \mathrm{Ab}$ \\
\hline \multirow{2}{*}{ Hybrid } & \multicolumn{2}{|c|}{32 DAE } & \multicolumn{2}{|c|}{37 DAE } \\
\hline & With control & Without control & With control & Without control \\
\hline P3380HR ${ }^{\circledR}$ & $2.50 \pm 1.04 \mathrm{Aa}$ & $6.00 \pm 1.58 \mathrm{Aa}$ & $2.75 \pm 1.75 \mathrm{Ba}$ & $5.50 \pm 1.50 \mathrm{Aab}$ \\
\hline P3431VYH ${ }^{\circledR}$ & $0.00 \pm 0.00 \mathrm{Ab}^{*}$ & $0.00 \pm 0.00 \mathrm{Ac}^{*}$ & $0.00 \pm 0.00 \mathrm{Ab}^{*}$ & $0.00 \pm 0.00 \mathrm{Ac}^{*}$ \\
\hline MG600PW $^{\circledR}$ & $0.00 \pm 0.00 \mathrm{Bb}^{*}$ & $1.75 \pm 0.62 \mathrm{Ab}$ & $0.25 \pm 0.25 \mathrm{Aa}$ & $1.75 \pm 0.25 \mathrm{Ab}$ \\
\hline DefenderVIP ${ }^{\circledR}$ & $0.00 \pm 0.00 \mathrm{Ab}^{*}$ & $0.00 \pm 0.00 \mathrm{Ac}^{*}$ & $0.00 \pm 0.00 \mathrm{Bb}^{*}$ & $1.00 \pm 0.70 \mathrm{Ab}$ \\
\hline $\mathrm{DKB}^{290 P R O 3}{ }^{\circledR}$ & $1.00 \pm 0.70 \mathrm{Aa}$ & $4.00 \pm 0.91 \mathrm{Aa}$ & $1.25 \pm 0.75 \mathrm{Ba}$ & $4.50 \pm 0.28 \mathrm{Aab}$ \\
\hline $\mathrm{NS70}{ }^{\circledR}$ & $2.50 \pm 1.55 \mathrm{Aa}$ & $3.00 \pm 1.08 \mathrm{Aa}$ & $2.75 \pm 1.18 \mathrm{Ba}$ & $8.50 \pm 1.70 \mathrm{Aa}$ \\
\hline \multirow{2}{*}{ Hybrid } & \multicolumn{2}{|c|}{42 DAE } & \multicolumn{2}{|c|}{47 DAE } \\
\hline & With control & Without control & With control & Without control \\
\hline $\mathrm{P}^{3} 380 \mathrm{HR}^{\circledR}$ & $2.25 \pm 0.85 \mathrm{Ba}$ & $8.25 \pm 2.49 \mathrm{Aa}$ & $2.75 \pm 1.10 \mathrm{Ba}$ & $2.50 \pm 0.95 \mathrm{Ab}$ \\
\hline P3431VYH ${ }^{\circledR}$ & $0.00 \pm 0.00 \mathrm{Ab}^{*}$ & $0.00 \pm 0.00 \mathrm{Ac}^{*}$ & $0.00 \pm 0.00 \mathrm{Bb}^{*}$ & $0.25 \pm 0.25 \mathrm{Ab}$ \\
\hline MG600PW $^{\circledR}$ & $2.25 \pm 0.62 \mathrm{Aa}$ & $3.75 \pm 1.93 \mathrm{Ab}$ & $0.75 \pm 0.47 \mathrm{Aa}$ & $1.50 \pm 0.64 \mathrm{Ab}$ \\
\hline DefenderVIP $^{\circledR}$ & $0.00 \pm 0.00 \mathrm{Bb}^{*}$ & $1.25 \pm 0.75 \mathrm{Ab}$ & $0.00 \pm 0.00 \mathrm{Bb}^{*}$ & $1.50 \pm 0.64 \mathrm{Ab}$ \\
\hline DKB290PRO3 ${ }^{\circledR}$ & $0.75 \pm 0.47 \mathrm{Aa}$ & $2.50 \pm 0.86 \mathrm{Ab}$ & $0.75 \pm 0.47 \mathrm{Aa}$ & $1.75 \pm 0.25 \mathrm{Ab}$ \\
\hline $\mathrm{NS}^{\circledR}{ }^{\circledR}$ & $3.00 \pm 1.08 \mathrm{Ba}$ & $9.50 \pm 1.55 \mathrm{Aa}$ & $4.25 \pm 1.70 \mathrm{Ba}$ & $7.50 \pm 1.19 \mathrm{Aa}$ \\
\hline
\end{tabular}

*There was no variability.

Uppercase letters compare lines and lowercase letters compare columns. The data were compared by contrasts of the negative binomial models at $5 \%$ of probability $(\mathrm{P}<0.05)$. 
At 42 DAE, it was observed a higher mean number of caterpillars in the field, only with the genotype containing the Leptra ${ }^{\circledR}$ technology without any S. frugiperda prevailing. This genotype is result of an event with Bt proteins stacking. This stacking employment favors the delay of evolution of resistance to Bt proteins, besides promoting a plague control more efficient than when individual events were employed (STORER et al., 2012; NIU et al., 2014). However, at $47 \mathrm{DAE}$, the genotype containing the Herculex ${ }^{\circledR}$ technology presented reduction in the mean number of caterpillars, not statistically differing from the others Bt maize genotypes in the absence of control. The non-Bt genotype differed from the rest with the highest mean number of

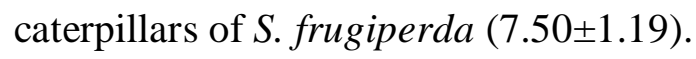

Regarding the mean lesions notes of $S$. frugiperda, it was possible to observe that there was significant difference between the treatments (Table 3). The highest foliar lesions notes, in a general way, were observed on the non-Bt hybrid and on the transgenics with Herculex ${ }^{\circledR}$, VT PRO $3^{\circledR}$, Powercore ${ }^{\circledR}$ technologies.

Hybrids with Herculex ${ }^{\circledR}$ and VT PRO $3{ }^{\circledR}$ technologies and the non-Bt hybrid presented, in at least one of the evaluations, lesions notes superior to 4 in the absence of plague control, behaving as susceptible to S. frugiperda. Barcelos \& Angelini (2018), evaluating different Bt technologies in the control of S. frugiperda in maize, obtained lesions notes above 3 in $20 \%$ of

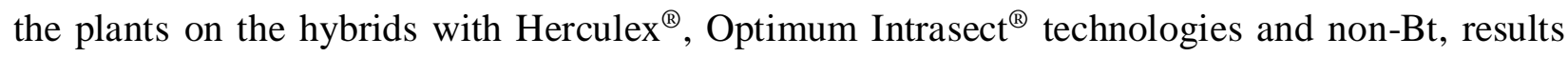
that are similar to the ones observed on this work.

At 12 DAE, the hybrids containing VT PRO $3^{\circledR}$ technology and the non-Bt were the only ones that significantly differed in relation to foliar lesions for presence or absence of control. At 17 DAE, there was no significant difference for control or no control of the plague. Yet at 22 $\mathrm{DAE}$, it was possible to observe lesions notes superior to 3 for the first time on the genotype containing the Herculex ${ }^{\circledR}$ technology and on non-Bt. Moraes et al. (2015) also observed significant increase of lesions notes with the course of time and more elevated on the non-Bt hybrids. 
Table 3. Mean notes \pm standard error of foliar lesions of Spodoptera frugiperda in maize of different Bt technologies, according to the adapted Davis et al. (1992) scale, at 12, 17, $22,27,32,37,42$, and 47 days after emergence of the culture. Dourados, Mato Grosso do Sul State, Brazil, 2019.

\begin{tabular}{|c|c|c|c|c|}
\hline \multirow{2}{*}{ Hybrid } & \multicolumn{2}{|c|}{12 DAE } & \multicolumn{2}{|c|}{17 DAE } \\
\hline & With control & Without control & With control & Without control \\
\hline P3380HR ${ }^{\circledR}$ & $1.30 \pm 0.17 \mathrm{Aa}$ & $1.35 \pm 0.15 \mathrm{Aab}$ & $1.40 \pm 0.24 \mathrm{Aa}$ & $1.60 \pm 0.15 \mathrm{Aab}$ \\
\hline P3431VYH ${ }^{\circledR}$ & $1.02 \pm 0.02 \mathrm{Ac}$ & $1.02 \pm 0.02 \mathrm{Ac}$ & $1.075 \pm 0.02 \mathrm{Aa}$ & $1.10 \pm 0.05$ Aabc \\
\hline MG600PW $^{\circledR}$ & $1.40 \pm 0.04 \mathrm{Aa}$ & $1.45 \pm 0.29 \mathrm{Aab}$ & $1.10 \pm 0.09 \mathrm{Aa}$ & $1.20 \pm 0.09$ Aabc \\
\hline DefenderVIP ${ }^{\circledR}$ & $1.07 \pm 0.04 \mathrm{Abc}$ & $1.05 \pm 0.02 \mathrm{Abc}$ & $1.05 \pm 0.02 \mathrm{Aa}$ & $1.05 \pm 0.05 \mathrm{Ac}$ \\
\hline DKB290PRO3 $^{\circledR}$ & $1.00 \pm 0.00 \mathrm{Bc}$ & $1.25 \pm 0.09 \mathrm{Ab}$ & $1.35 \pm 0.16 \mathrm{Aa}$ & $1.90 \pm 0.19 \mathrm{Aa}$ \\
\hline $\mathrm{NS70}{ }^{\circledR}$ & $1.17 \pm 0.06 \mathrm{Bab}$ & $1.57 \pm 0.13 \mathrm{Aa}$ & $1.47 \pm 0.25 \mathrm{Aa}$ & $2.05 \pm 0.38 \mathrm{Aa}$ \\
\hline \multirow{2}{*}{ Hybrid } & \multicolumn{2}{|c|}{22 DAE } & \multicolumn{2}{|c|}{27 DAE } \\
\hline & With control & Without control & With control & Without control \\
\hline P3380HR ${ }^{\circledR}$ & $1.55 \pm 0.38 \mathrm{Bb}$ & $4.47 \pm 0.71 \mathrm{Aa}$ & $2.07 \pm 0.29 \mathrm{Aa}$ & $1.37 \pm 0.68 \mathrm{Aa}$ \\
\hline P3431VYH ${ }^{\circledR}$ & $1.00 \pm 0.00 \mathrm{Ac}$ & $1.05 \pm 0.05 \mathrm{Ab}$ & $1.00 \pm 0.00 \mathrm{Ac}$ & $1.00 \pm 0.00 \mathrm{Ac}$ \\
\hline MG600PW ${ }^{\circledR}$ & $1.27 \pm 0.15 \mathrm{Ab}$ & $1.82 \pm 0.14 \mathrm{Aa}$ & $1.10 \pm 0.10 \mathrm{Bc}$ & $1.50 \pm 0.18 \mathrm{Ab}$ \\
\hline DefenderVIP ${ }^{\circledR}$ & $1.02 \pm 0.02 \mathrm{Abc}$ & $1.10 \pm 0.05 \mathrm{Ab}$ & $1.00 \pm 0.00 \mathrm{Ac}$ & $1.05 \pm 0.02 \mathrm{Ac}$ \\
\hline DKB290PRO3 $^{\circledR}$ & $1.37 \pm 0.21 \mathrm{Bb}$ & $2.55 \pm 0.40 \mathrm{Aa}$ & $1.30 \pm 0.14 \mathrm{Bbd}$ & $2.75 \pm 0.32 \mathrm{Aa}$ \\
\hline $\mathrm{NS70}{ }^{\circledR}$ & $2.20 \pm 0.54 \mathrm{Aa}$ & $3.17 \pm 0.72 \mathrm{Aa}$ & $1.47 \pm 0.24 \mathrm{Ab}$ & $2.00 \pm 0.14 \mathrm{Aab}$ \\
\hline \multirow{2}{*}{ Hybrid } & \multicolumn{2}{|c|}{32 DAE } & \multicolumn{2}{|c|}{37 DAE } \\
\hline & With control & Without control & With control & Without control \\
\hline P3380HR ${ }^{\circledR}$ & $1.87 \pm 0.30 \mathrm{Ba}$ & $3.87 \pm 0.75 \mathrm{Aa}$ & $2.20 \pm 0.38 \mathrm{Ba}$ & $3.42 \pm 0.66 \mathrm{Aa}$ \\
\hline P3431VYH ${ }^{\circledR}$ & $1.00 \pm 0.00 \mathrm{Ac}$ & $1.00 \pm 0.00 \mathrm{Ac}$ & $1.00 \pm 0.00 \mathrm{Ab}$ & $1.07 \pm 0.04 \mathrm{Ac}$ \\
\hline MG600PW $^{\circledR}$ & $1.02 \pm 0.02 \mathrm{Bc}$ & $1.80 \pm 0.43 \mathrm{Ab}$ & $1.22 \pm 0.19 \mathrm{Bb}$ & $1.77 \pm 0.18 \mathrm{Abc}$ \\
\hline DefenderVIP ${ }^{\circledR}$ & $1.00 \pm 0.00 \mathrm{Ac}$ & $1.00 \pm 0.00 \mathrm{Ac}$ & $1.00 \pm 0.00 \mathrm{Bb}$ & $1.37 \pm 0.34 \mathrm{Ac}$ \\
\hline $\mathrm{DKB}^{290 P R O}{ }^{\circledR}$ & $1.20 \pm 0.12 \mathrm{Bbc}$ & $2.95 \pm 0.15 \mathrm{Aa}$ & $1.45 \pm 0.27 \mathrm{Bb}$ & $2.62 \pm 0.35 \mathrm{Aab}$ \\
\hline $\mathrm{NS} 70^{\circledR}$ & $1.95 \pm 0.55 \mathrm{Bb}$ & $2.60 \pm 0.38 \mathrm{Aa}$ & $2.22 \pm 0.23 \mathrm{Ba}$ & $5.07 \pm 0.89 \mathrm{Aa}$ \\
\hline \multirow{2}{*}{ Hybrid } & \multicolumn{2}{|c|}{42 DAE } & \multicolumn{2}{|c|}{47 DAE } \\
\hline & With control & Without control & With control & Without control \\
\hline P3380HR ${ }^{\circledR}$ & $1.87 \pm 0.22 \mathrm{Ba}$ & $5.12 \pm 0.77 \mathrm{Aab}$ & $1.92 \pm 0.24 \mathrm{Bbc}$ & $2.90 \pm 0.74 \mathrm{Aab}$ \\
\hline P3431VYH ${ }^{\circledR}$ & $1.00 \pm 0.00 \mathrm{Ab}$ & $1.00 \pm 0.00 \mathrm{Ad}$ & $1.00 \pm 0.00 \mathrm{Ac}$ & $1.07 \pm 0.07 \mathrm{Ac}$ \\
\hline MG600PW $^{\circledR}$ & $1.62 \pm 0.04 \mathrm{Aa}$ & $2.25 \pm 0.34 \mathrm{Ac}$ & $1.27 \pm 0.24 \mathrm{Bc}$ & $1.82 \pm 0.20 \mathrm{Ab}$ \\
\hline DefenderVIP ${ }^{\circledR}$ & $1.00 \pm 0.00 \mathrm{Ab}$ & $1.25 \pm 0.15 \mathrm{Ad}$ & $1.00 \pm 0.00 \mathrm{Bc}$ & $1.57 \pm 0.27 \mathrm{Abc}$ \\
\hline $\mathrm{DKB}_{290 \mathrm{PRO}}{ }^{\circledR}$ & $1.12 \pm 0.09 \mathrm{Bb}$ & $2.45 \pm 0.37 \mathrm{Abc}$ & $1.35 \pm 0.23 \mathrm{Bc}$ & $1.80 \pm 0.15 \mathrm{Ab}$ \\
\hline $\mathrm{NS70}{ }^{\circledR}$ & $2.37 \pm 0.52 \mathrm{Ba}$ & $5.35 \pm 0.68 \mathrm{Aa}$ & $2.26 \pm 0.77 \mathrm{Ba}$ & $5.22 \pm 0.35 \mathrm{Aa}$ \\
\hline
\end{tabular}

Uppercase letters compared lines and lowercase letters compare columns. The data were compared by the Friedman test at $5 \%$ of probability $(\mathrm{P}<0.05)$. 
However, in our study, besides the non-Bt hybrid, the hybrids containing the Herculex ${ }^{\circledR}$ and VT PRO $3^{\circledR}$ technologies also presented higher notes. Besides that, these hybrids containing Hercule ${ }^{\circledR}$ and VT PRO $3{ }^{\circledR}$ presented significant differences for presence and absence of control. The lowest means of foliar lesions, without control, were obtained by the hybrids containing the Leptra ${ }^{\circledR}$ and Viptera $3^{\circledR}$ technologies, demonstrating the efficiency of the Vip3a20 protein on the control of S. frugiperda, as already described by Michelotto et al. (2017) when evaluating the behavior of $\mathrm{Bt}$ maize cultivars in relation to attack of lepidopterans.

After 27 days of emergence of plants, only the hybrids with Powercore ${ }^{\circledR}$ and VT PRO $3^{\circledR}$ technologies presented significant statistical differences for the presence or absence of $S$. frugiperda control. At $32 \mathrm{DAE}$, in the absence of plague chemical control, the lowest means of lesions were obtained by the hybrids containing Leptra ${ }^{\circledR}$ and Viptera $3^{\circledR}$ technologies, followed by Powercore ${ }^{\circledR}$. The other genotypes did not present significant difference between each other, showing themselves to be susceptible to the attack of the $S$. frugiperda populations.

At $37 \mathrm{DAE}$, when foliar lesions mean notes were evaluated, only the hybrid containing Leptra $^{\circledR}$ technology did not differ significantly regarding control, demonstrating that is still being an efficient technology of the plague.

Yet at $42 \mathrm{DAE}$, when submitted to the chemical control of the plague, the lowest means of foliar lesions were obtained by the hybrids containing the Leptra ${ }^{\circledR}$, Viptera $3^{\circledR}$ and VT PRO $3^{\circledR}$ technologies, not differing statistically between each other. In the absence of control, the hybrids that presented the highest means for lesions were the hybrids containing the Herculex ${ }^{\circledR}$ technology and the non-Bt hybrid. In this period, there was no significant difference for the plague control on Leptra ${ }^{\circledR}$, Powercore ${ }^{\circledR}$ and Viptera $3^{\circledR}$ technologies.

At 47 DAE, the only hybrid that did not present significant difference for control or no control of the plague with insecticide was the one with Leptra ${ }^{\circledR}$ technology. The efficiency of this technology can be explained by the stacking of the Vip3a20 protein with proteins Cry1F and Cry1 Ab, yet reinforcing the elevated effectiveness of the Vip3a20 protein for control of the plague (ZHU et al., 2019). The importance of stacking was already reinforced by Zhu et al. (2019) as strategy in management in order to avoid the resistance of this plague-insect. Even with control of $S$. frugiperda, the non-Bt maize hybrid reached the highest damage mean $(2.26 \pm 0.77)$ and in the absence of control it also presented the higher mean, however not differing statistically from the hybrid with Herculex ${ }^{\circledR}$ technology. 
For variables weight, one thousand grains mass and final stand there was no significant difference among the control conditions when submitted to Kruskal-Wallis test $(\mathrm{P}=0.05)$, as observed on Table 4.

Table 4. Estimative of productivity of hybrids and mean \pm standard error of the percentage of difference of grain weight, one thousand grains weight, and final stand of different $\mathrm{Bt}$ maize hybrids in conditions of absence of control and when conducted the chemical control of Spodoptera frugiperda. Dourados, Mato Grosso do Sul State, Brazil, 2019.

\begin{tabular}{|c|c|c|c|c|c|}
\hline Hybrid & $\begin{array}{l}\text { Without } \\
\text { control } \\
\left(\mathrm{kg} \mathrm{ha}^{-1}\right)^{*}\end{array}$ & $\begin{array}{l}\text { With control } \\
\left(\mathrm{kg} \mathrm{ha}^{-1}\right)^{*}\end{array}$ & Weight (Kg ha $\left.{ }^{-1}\right)$ & $\begin{array}{l}\text { One thousand } \\
\text { grains weight }\end{array}$ & Stand \\
\hline P3380HR ${ }^{\circledR}$ & 5347.79 & 5716.95 & $05.19 \pm 10.66 \mathrm{a}$ & $03.62 \pm 11.26 \mathrm{a}$ & $02.35 \pm 7.00 \mathrm{a}$ \\
\hline P3431VYH ${ }^{\circledR}$ & 6276.91 & 7004.57 & $10.71 \pm 2.76 \mathrm{a}$ & $06.34 \pm 4.13 \mathrm{a}$ & $01.66 \pm 5.40 \mathrm{a}$ \\
\hline MG600PW $^{\circledR}$ & 6213.85 & 7435.58 & $16.41 \pm 5.14 \mathrm{a}$ & $-01.39 \pm 3.65 \mathrm{a}$ & $-12.17 \pm 7.28 \mathrm{a}$ \\
\hline DefenderVIP ${ }^{\circledR}$ & 4995.29 & 6130.05 & $17.94 \pm 7.19 \mathrm{a}$ & $01.26 \pm 3.45 \mathrm{a}$ & $00.00 \pm 0.00 \mathrm{a}$ \\
\hline$\underset{\circledast}{\mathrm{DKB} 290 \mathrm{PRO} 3}$ & 5392.65 & 5530.69 & $0.62 \pm 10.67 \mathrm{a}$ & $03.79 \pm 10.41 \mathrm{a}$ & $-02.00 \pm 11.09 \mathrm{a}$ \\
\hline $\mathrm{NS70}{ }^{\circledR}$ & 6545.66 & 6555.91 & $-0.30 \pm 9.34 \mathrm{a}$ & $01.17 \pm 3.92 \mathrm{a}$ & $-12.40 \pm 12.40 \mathrm{a}$ \\
\hline Critical value & - & - & 4.01 & 1.79 & 3.16 \\
\hline GL & - & - & 5 & 5 & 5 \\
\hline P-value of $\chi^{2}$ & - & - & 0.5479 & 0.8773 & 0.6749 \\
\hline
\end{tabular}

Means compared by the Kruskal-Wallis test $(\mathrm{P}=0.05)$ on the columns. *Estimative of productivity.

It can be observed that for variables plant height, reed diameter and number of cobs there was no significant difference between treatments by Kruskal-Wallis test $(\mathrm{P}=0.05)$ (Table 5), as for variables number of grains per cob, number of rows and length of cob (Table 6) when compared the difference between treatments with and without chemical control of S. frugiperda, estimated in percentage. Hybrids were not compared because they have different genotypes.

These results can be explained by the fact of the $S$. frugiperda infestation in the area having occurred naturally. There was observed moderate incidence and it remained stable for practically the whole culture cycle. This reflected at eh mean levels of foliar lesions caused by the plague, which was superior to note 3 for few times in the absence of control. In accord with the recommendation of ABRASEM (2014), there is a necessity of plague control when $20 \%$ of the plants present lesion notes equal or superior to 3, in the Davis et al., (1992) scale. On the other hand and based in our study, this recommendation can be way below the level of economic damage of the plague, working almost as a prevention measure due to the difficulty of plague control in infestations more elevated and with bigger caterpillars. 
Table 5. Mean \pm standard error of the percentage of difference of plant height, reed diameter and number of cobs of different Bt maize hybrids in conditions of absence of control and when conducted chemical control of Spodoptera frugiperda. Dourados, Mato Grosso do Sul State, Brazil, 2019.

\begin{tabular}{cccc}
\hline Hybrid & Height $(\mathbf{c m})$ & Diameter $(\mathbf{m m})$ & Number of Cobs \\
\hline P3380HR $^{\circledR}$ & $05.10 \pm 3.94 \mathrm{a}$ & $-01.86 \pm 2.49 \mathrm{a}$ & $-08.34 \pm 3.00 \mathrm{a}$ \\
P3431VYH $^{\circledR}$ & $07.69 \pm 2.96 \mathrm{a}$ & $09.29 \pm 5.17 \mathrm{a}$ & $-03.65 \pm 17.35 \mathrm{a}$ \\
MG600PW $^{\circledR}$ & $00.65 \pm 4.12 \mathrm{a}$ & $02.60 \pm 2.32 \mathrm{a}$ & $02.82 \pm 4.51 \mathrm{a}$ \\
DefenderVIP $^{\circledR}$ & $01.74 \pm 1.52 \mathrm{a}$ & $01.68 \pm 4.35 \mathrm{a}$ & $-01.64 \pm 7.75 \mathrm{a}$ \\
DKB290PRO3 $^{\circledR}$ & $-02.99 \pm 0.67 \mathrm{a}$ & $-05.21 \pm 3.45 \mathrm{a}$ & $-06.45 \pm 11.18 \mathrm{a}$ \\
NS70 $^{\circledR}$ & $03.67 \pm 4.66 \mathrm{a}$ & $01.17 \pm 4.07 \mathrm{a}$ & $-14.89 \pm 2.96 \mathrm{a}$ \\
\hline Critical value & 6.69 & 6.11 & 5.55 \\
\hline GL & 5 & 5 & 5 \\
\hline P-value of $\boldsymbol{\chi}^{\mathbf{2}}$ & 0.2447 & 0.2956 & 0.3517 \\
\hline
\end{tabular}

Means compared by Kruskal-Wallis test $(\mathrm{P}=0.05)$ on the columns.

Table 6. Mean \pm standard error of percentage of difference of number of grains per cob, number of row and length of the cobs of different Bt maize hybrids in conditions of absence of control and when conducted the chemical control of Spodoptera frugiperda. Dourados, Mato Grosso do Sul State, Brazil, 2019.

\begin{tabular}{cccc}
\hline Hybrid & Number of Grains & Number of Row & Length of cob (cm) \\
\hline P3380HR ${ }^{\circledR}$ & $02.28 \pm 4.78 \mathrm{a}$ & $-01.76 \pm 1.02 \mathrm{a}$ & $-01.28 \pm 2.81 \mathrm{a}$ \\
P3431VYH $^{\circledR}$ & $-07.11 \pm 7.70 \mathrm{a}$ & $-01.23 \pm 1.74 \mathrm{a}$ & $-03.20 \pm 3.77 \mathrm{a}$ \\
MG600PW $^{\circledR}$ & $11.17 \pm 4.65 \mathrm{a}$ & $03.36 \pm 1.60 \mathrm{a}$ & $02.84 \pm 1.88 \mathrm{a}$ \\
DefenderVIP $^{\circledR}$ & $-01.28 \pm 5.97 \mathrm{a}$ & $-02.41 \pm 2.61 \mathrm{a}$ & $00.53 \pm 2.33 \mathrm{a}$ \\
DKB290PRO3 $^{\circledR}$ & $01.58 \pm 2.06 \mathrm{a}$ & $03.52 \pm 1.89 \mathrm{a}$ & $01.92 \pm 1.50 \mathrm{a}$ \\
NS70 $^{\circledR}$ & $-00.72 \pm 7.18 \mathrm{a}$ & $01.62 \pm 1.44 \mathrm{a}$ & $-00.96 \pm 2.44 \mathrm{a}$ \\
\hline Critical value & 4.76 & 8.97 & 3.75 \\
\hline GL & 5 & 5 & 5 \\
\hline P-value of $\chi^{\mathbf{2}}$ & 0.4458 & 0.1101 & 0.5859 \\
\hline
\end{tabular}

Means compared by the Kruskal-Wallis test $(\mathrm{P}=0.05)$ on the columns. 


\section{CONCLUSION}

The lowest means for number of caterpillars and foliar lesion notes caused by $S$. frugiperda were verified on hybrids with Viptera $3^{\circledR}$ and Leptra ${ }^{\circledR}$ technologies, presenting efficiency in the control of this pest, while Herculex ${ }^{\circledR}$ technology is not effective in the control of S. frugiperda.

In this way, there are maize genotypes resistant to $S$. frugiperda, however, there was no significant difference for the productive parameters of the different corn hybrids in conditions of no control and when the chemical control of $S$. frugiperda was carried out under the conditions of infestations that occurred in this study. This suggests that the levels of economic damage of $S$. frugiperda on corn crop are higher than the levels of infestation occurred in the study.

\section{REFERENCES}

ABRASEM (ASSOCIAÇÃO BRASILEIRA DE SEMENTES E MUDAS), 2014. Boas práticas agronômicas aplicadas a plantas geneticamente modificadas resistentes a insetos. Associação Brasileira de Sementes e Mudas. p. 33. (Informativo técnico).

BARCELOS, P. H. S.; ANGELINI, M. R., 2018. Controle de Spodoptera frugiperda (Smith, 1797) em diferentes tecnologias Bts (Bacillus thuringienses) na cultura do milho. Revista de Agricultura Neotropical, Cassilândia, v.5, n.1, p.35-40.

BERNARDI, D.; BERNARDI, O.; HORIKOSHI, R. J.; SALMERON, E.; OKUMA, D. M.; FARIAS, J. R.; NASCIMENTO, A. R. B.; OMOTO, C., 2017. Selection and characterization of Spodoptera frugiperda (Lepidoptera: Noctuidae) resistance to MON $89034 \times$ TC1507 $\times$ NK603 maize technology. Crop Protection, Oxford, v.94, p.64-68.

BERNARDI, D.; SALMERON, E.; HORIKOSHI, R. J.; BERNARDI, O.; DOURADO, P. M.; CARVALHO, R. A.; MARTINELI, S.; HEAD, G. P.; OMOTO C., 2015b. Cross-resistance between Cry1 proteins in fall armyworm (Spodoptera frugiperda) may affect the durability of current pyramided Bt maize hybrids in Brazil. PLoS One, San Francisco, v.10, e0140130. BERNARDI, O.; BERNARDI, D.; HORIKOSHI, R. J.; OKUMA, D. M.; MIRALDO, L. L.; FATORETTO, J.; MEDEIROS, F. C. L.; BURD, T.; OMOTO, C., 2016. Selection and characterization of resistance to the Vip3Aa20 protein from Bacillus thuringiensis in Spodoptera frugiperda. Pest Management Science, Hoboken, v.72, 1794-1802.

BERNARDI, O.; BERNARDI, D.; AMADO, D.; SOUSA, R. S.; FATORETTO, J.; MEDEIROS, F. C., 2015a. Resistance risk assessment of Spodoptera frugiperda (Lepidoptera: Noctuidae) and Diatraea saccharalis (Lepidoptera: Crambidae) to Vip3Aa20 insecticidal protein expressed in corn. Journal of Economic Entomology, Annapolis, v.108, p. 2711-2719.

BRASIL. Ministério da Agricultura, Pecuária e Abastecimento, 2009. Regras para Análise de Sementes. Ministério da Agricultura, Pecuária e Abastecimento. Secretaria de Defesa Agropecuária. Brasília, DF: Mapa/ACS. p.398.

CÉLERES, 2017. 3rd follow-up on agricultural biotechnology adoption for the 2016/17 crop. Available at: http://www.celeres.com.br/. Access in: May 20, 2019.

COMISSÃO TÉCNICA NACIONAL DE BIOSSEGURANÇA, 2018. Resumo Geral de Plantas Geneticamente modificadas e aprovadas para comercialização. Available 
at:<http://ctnbio.mcti.gov.br/liberacaocomercial//document_library_display/SqhWdohU4Bv

U/view/1684467\#/liberacao-comercial>. Access in Nov. 01, 2018.

CONAB (COMPANHIA NACIONAL DE ABASTECIMENTO), 2018. Acompanhamento da safra brasileira Grãos. Brasília-DF. v.5 safra 2017/2018. n. 9 - nono levantamento. Available at: <http://www.conab.gov.br >. Access in: May 09, 2019.

MICHELOTTO, M. D., CROSARIOL NETO, J., PIROTTA, M. Z., DUARTE, A. P., FEITAS, R. S., FINOTO, E. L., 2017. Eficácia de milho transgênico tratado com inseticida no controle da lagarta-do-cartucho no milho safrinha no estado de São Paulo, Brasil. Ciência e Agrotecnologia, Lavras, v. 41, n. 2, p. 128-138.

CRUZ, I.; FIGUEIREDO, M.; SILVA, R. B.; SILVA, I. F.; PAULA, C. S.; FOSTER, J. E., 2012. Using sex pheromone traps in the decision-making process for pesticide application against fall armyworm (Spodoptera frugiperda (Smith) (Lepidoptera: Noctuidae)) larvae in maize. Pest Management Science, Hoboken, v. 58, p.83-90.

DAVIS, F. M.; NG, S. S.; WILLIANS, W. P., 1992. Visual rating scales for screening whorl stage corn for resistance to fall armyworm. Technical bulletin - Mississippi Agricultural and Forestry Experiment Station (USA). n. 186, p. 9.

DUARTE, J. O.; MATTOSO, M. J.; GARCIA, J. C., 2017 Milho - Importância socioeconômica.

Available

at: <http://www.agencia.cnptia.embrapa.br/gestor/milho/arvore/CONTA01_8_168200511157.ht ml.> Access in: May 18, 2019.

FARIAS, J. R.; ANDROW, D. A., HORIKOSHI, R. J., SORGATTO, R. J., FRESIA, P., SANTOS, A. C., OMOTO, C., 2014. Field-evolved resistance to Cry1F maize by Spodoptera frugiperda (Lepidoptera: Noctuidae) in Brazil. Crop Protection, Oxford. v.64, p.150-158.

MORAES, A. R. A.; LOURENÇÃO, A. L.; PATERNIANI, M. E. A. G. Z., 2015. Resistência de híbridos de milho convencionais e isogênicos transgênicos a Spodoptera frugiperda (Lepidoptera: Noctuidae). Bragantia, Campinas, v.74, n.1, p.50-57.

NIU, Y.; YANG, F.; DANGAL, V.; HUANG, F., 2014. Larval survival and plant injury of Cry1F - susceptible, - resistant, and - heterozygous fall armyworm (Lepidoptera: Noctuidae) on non-Bt and Bt corn containing single or pyramided genes. Crop Protection, Oxford. v. 59, p.22-28.

OMOTO, C.; BERNARDI, O.; SALMERON, E.; SORGATTO, R.J.; DOURADO, P.M.; CRIVELlARI, A.; CARVAlHO, R.A.; WILlSE, A.; MARTINELli, S.; HEAD, G.P., 2016. Field-evolved resistance to Cry1 Ab maize by Spodoptera frugiperda in Brazil. Pest Management Science, Hoboken, v. 72, p.1727-1736.

STORER, N. P.; KUBISZAK, M. E.; KING, J. E.; THOMPSON, G. D.; SANTOS, A. C., 2012. Status of resistance to $\mathrm{Bt}$ maize in Spodoptera frugiperda: lessons from Puerto Rico. Journal of Invertebrate Pathology, Amsterdam, v. 110, p.294-300.

TABASHNIK, B. E.; BRÉVAULT, T.; CARRIÈRE, Y., 2013. Insect resistance to Bt crops: lessons from the first billion acres. Nature Biotechnol, London, v. 31, p.510-521.

YU, S. J.; NGUYEN, S. N.; ABO-ELGHAR, G. E., 2003. Biochemical characterization of insecticide resistance in the fall armyworm. Pesticide Biochemistry and Physiology, Amsterdam v. 77, n.1, p.1-11.

ZHU, C.; NIU, Y.; ZHOU, Y.; GUO, J.; HEAD, G. P.; PRICE, P. A.; WEN, X.; HUANG, F., 2019. Survival and effective dominance level of a Cry1A.105/Cry2Ab2-dual gene resistant population of Spodoptera frugiperda (J.E. Smith) on common pyramided Bt corn traits. Crop Protection, Oxford. v. 115, p.84-91. 
Received in: February 17, 2020

Accepted in: April 28, 2020 